\title{
Challenges Faced by Lady Surgeons during Professional Progress in Pakistan
}

\author{
Amna Ahmed Noor ${ }^{1}$, Wajiha Shadab ${ }^{2}$ and Saira Waqqar ${ }^{3}$ \\ ${ }^{1}$ Department of Medical Education, Mohtarma Benazir Bhutto Shaheed Medical College, Mirpur, Azad Kashmir, Pakistan \\ ${ }^{2}$ Department of Obs \& Gynae, Islamic International Medical Collage Trust, Riphah International University, Islamabad, Pakistan \\ ${ }^{3}$ Department of Physical Therapy, Riphah College of Rehabilitation and Allied Health Sciences, Riphah International University, \\ Islamabad, Pakistan
}

\begin{abstract}
The purpose of this qualitative study was to investigate the professional challenges faced by lady surgeons in Pakistan. This qualitative exploratory phenomenological study was conducted from April 2019 to June 2019. Four lady surgeons participated in in-depth interviews, based on four questions: challenges during training; perceptions of gender-based professional treatment; perceptions of relationships with peers; and perception of gender on the quality of training. Four main themes with ten subthemes were developed. Family support is identified as major facilitating factor. Participants experienced gender-based discrimination at workplace, long exhausting duty hours with lack of quality time for their families and social gatherings. With the passage of time, these problems diminished as the surgeons gained a work-life balance with their motivation.
\end{abstract}

Key Words: Barriers, Career progression Challenges, Lady surgeons, Gender.

How to cite this article: Noor AA, Shadab W, Waqqar S. Challenges Faced by Lady Surgeons during Professional Progress in Pakistan. J Coll Physicians Surg Pak 2021; 31(09):1123-1125.

Out of the world's total population of 7.6 billion, women contribute 3.8 billion. ${ }^{1,2}$ The rise in women population worldwide demands a proportionate increase in the number of lady doctors. Increasingly, lady doctors are preferred by women socially and psychologically. ${ }^{2,3}$ Consequently, the number of female students in medical colleges has increased in the $21^{\text {st }}$ century, but the number of practicing lady doctors has not been increased adequately. ${ }^{3}$

Despite outperforming their male counterparts in medical schools, an increasing number of lady doctors quit their profession after graduation in developing countries. This trend not only leads to a reduction in total number of practicing lady doctors, but also results in significant reduction in women representation in certain specialties - particularly, the surgical sub-specialties. ${ }^{2}$ Increase in demand of lady surgeons is multifactorial. ${ }^{2,3}$ There is a need to explore the factors responsible for insufficient number of practicing lady surgeons, despite increasing number of graduating surgeons.

Correspondence to: Dr. Saira Waqqar, Department of Physical Therapy, Riphah College of Rehabilitation and Allied Health Sciences, Riphah International University, Islamabad, Pakistan

E-mail: sairawaqqar@yahoo.com

Received: February 15, 2021; Revised: April 12, 2021;

Accepted: May 04, 2021

DOI: https://doi.org/10.29271/jcpsp.2021.09.1123
This qualitative exploratory phenomenological study was conducted after approval of Institutional Review Board, Research Ethical Committee of Islamic International Medical College, Rawalpindi (Ref. No. 0312). The set of questions was used during semi-structured interviews to explore the challenges that lady surgeons faced during their postgraduate training. Purposive sampling technique was used to choose the participants. Data was collected through face-to-face interviews from four lady surgeons, one from each selected hospital, i.e. Railways General Hospital and Combined Military Hospital, Rawalpindi, Abbas Institute of Medical Sciences, and Combined Military Hospital, Muzaffarabad. The selected participants were associate professors and professors of surgical specialties in ear, nose and throat (ENT), ophthalmic surgery, and general surgery departments. Lady surgeons, who were retired, did not complete residency training, did not pass residency exit exam in at least two attempts and were personal acquaintances of the primary investigator, were excluded from the study. Data was collected from April 2019 to June 2019.The interviews were audio-recorded. Themes were defined manually on the basis of data transcription and codes. The coding of data was conducted in two stages. In the first cycle, open coding was performed and the emergent codes were listed. In the second step, axial coding was performed and emergent themes with sub-themes were extracted. Data validation was done through investigator triangulation. Initially, triangulation was done by the principal investigator. Later, two more investigators analysed the data independently. Four themes were identified: clinical challenges faced during residency, professional relationship with colleagues and patient, personal relationship and impact on family life, and motivational factor. 
Table I: Challenges faced by lady surgeons during professional career progress.

\begin{tabular}{|c|c|c|c|}
\hline Theme & Subtheme & Codes & Quotes \\
\hline \multirow{6}{*}{ Clinical Challenges } & \multirow{2}{*}{ Career start } & Doubt in competency & \multirow{2}{*}{$\begin{array}{l}\text { "Usually colleagues give remarks i.e. "to look after your home and do cooking } \\
\text { only."(AP:N\&TS) }\end{array}$} \\
\hline & & disregard & \\
\hline & \multirow{3}{*}{$\begin{array}{l}\text { workplace } \\
\text { associated } \\
\text { challenges }\end{array}$} & Over Workload & \multirow{3}{*}{$\begin{array}{l}\text { "It is very difficult to cope up with the daily routine matters that make me so } \\
\text { tired. This is just due to lack of supportive staff on workplace and too much } \\
\text { workload".(P:GS) }\end{array}$} \\
\hline & & Shortage of support system & \\
\hline & & Male Supremacy & \\
\hline & $\begin{array}{l}\text { Quality of Clinical } \\
\text { work }\end{array}$ & Demotivation on Strong nerves & $\begin{array}{l}\text { "Male colleagues have doubt on my way of practice although it is the same as } \\
\text { they work".(AP:ES) }\end{array}$ \\
\hline \multirow{4}{*}{$\begin{array}{l}\text { Professional } \\
\text { Relationships }\end{array}$} & \multirow{3}{*}{ Colleagues } & Respectful & \multirow{3}{*}{$\begin{array}{l}\text { "My colleagues always facilitate whenever I need leave because of my kids or } \\
\text { family problem."(P:OPS) }\end{array}$} \\
\hline & & Demeaning attitude & \\
\hline & & Discouraging & \\
\hline & Patients & Preference to female doctors & $\begin{array}{l}\text { "Throughout my professional practice till now, I found female patients prefer } \\
\text { female physician just because of their comfort; hardly someone said no."(P:GS) }\end{array}$ \\
\hline \multirow{6}{*}{$\begin{array}{l}\text { Personal } \\
\text { Relationships and } \\
\text { Impact on their } \\
\text { family life }\end{array}$} & \multirow[b]{2}{*}{ Spouse } & Supportive & \multirow{2}{*}{$\begin{array}{l}\text { "My husband was very co-operative and helped me a lot throughout children } \\
\text { brought up. He used to awake with me the whole night even feeding them } \\
\text { food." (AP:N\&TS) }\end{array}$} \\
\hline & & $\begin{array}{l}\text { Responsibility to look after } \\
\text { children and house holds }\end{array}$ & \\
\hline & \multirow[b]{2}{*}{ Kids } & No Day care facility & \multirow{2}{*}{$\begin{array}{l}\text { "Being a mother, It was really very difficult to handover my six months old } \\
\text { daughter to my mother. It was the time when I posted to health department on } \\
\text { other station and took back when my daughter was two years old."(P:GS) }\end{array}$} \\
\hline & & $\begin{array}{l}\text { Less time with Poor quality } \\
\text { care }\end{array}$ & \\
\hline & \multirow[b]{2}{*}{ In-Laws } & Supportive & \multirow{2}{*}{$\begin{array}{l}\text { "My professional growth is just because of my family support, especially In- } \\
\text { laws who take care of my kids and household responsibilities." ".(AP:ES) }\end{array}$} \\
\hline & & $\begin{array}{l}\text { Not supportive of career } \\
\text { choice }\end{array}$ & \\
\hline \multirow{3}{*}{ Motivational factors } & \multirow{2}{*}{ Enthusiasm } & Setting goals & \multirow{2}{*}{$\begin{array}{l}\text { "In early phase of professional career goal Setting is a key source of self- } \\
\text { motivation and ambition that I have to do and achieve it no matter what." } \\
\text { (P:OPS) }\end{array}$} \\
\hline & & Professional ambitions & \\
\hline & $\begin{array}{l}\text { Societal support } \\
\text { system }\end{array}$ & Supportive spouse and in- laws & “Definitely, No lady can work without her husband and In-laws support.”(P:GS) \\
\hline
\end{tabular}

Four out of two surgeons belonged to Rawalpindi; whereas, the others were from Muzaffarabad. The age ranged from 35 to 50 years. They were married and had school- or college-going children. All the four participants were physically stable belonging to middle class families.

Initially, open coding of all four interviews was done, followed by the axial coding to draw emergent four themes and 10 sub-themes, as shown in Table I.

It was found that lady surgeons face numerous challenges related to professional training in their initial part of career, along with long exhausting duty hours during training years. According to Nousheen et al., these long duty hours may lead to stress, anxiety, and burnout. Secondly, lady surgeons faced gender discrimination at their workplace. They have to face offensive and disparaging remarks from their male counterparts. They feel that they are constantly being overshadowed by male surgeons, irrationally winning their patients hindering their practice. Satisfying the professional demands of surgery are much challenging in itself and the additional problem of gender-based discrimination contributes to the existing pressure, leading to work-based stress. Disregard from male colleagues, sexual harassments were also major factors, further impeding women to elect the male-governing specialties, namely surgery. Day- care facilities are not of a satisfactory level in most hospitals of Pakistan, which is another discouraging reason. Male doctors think that a day-care centre distracts women from their duties. ${ }^{4}$

Contemporary study corroborates these factors and explicate the factors serving as obstacles contrasted with factors supporting women in career advancement. The participants in the current study explicated that their families, particularly husbands, were chief support during their career. This contributes to the opinion in that cases where women dropout. One of the major contributory factors is lack of family support. Consequently, the lady doctors must compromise their career, preferring family and their decisions over profession. The peculiar social and cultural circumstances of Pakistani society do not favour women performing duties with long working hours as required in surgical practice. Therefore, there is big deficiency of ladysurgeons in Pakistan having a population of 210 million people. ${ }^{5}$

This study discovered that the lady surgeons had to make changes in their personal lives adjusting their professional obligations, like missing social functions, counting on their partners and families for household tasks and sharing responsibilities of children. Sometimes, they have to compromise their responsibilities as a mother due to lack of time. Morris et al. highlights the idea that maintaining a balance between family and professional life is an uphill task for women demanding time management skills and devotion to both the profession and family life. ${ }^{6}$ In surgical profession, after long training work hours, family time is compromised. Current study indicates that only enthusiasm and passion for surgery with family support system motivates lady surgeons to accomplish their professional goals.

It is concluded that globally rising female population demands more practicing lady surgeons. Accordingly, Pakistan urgently needs a larger number of lady surgeons to meet this shortage for a 210-million population of the country. As per current study, the existing gap can be diminished through the support and encouragement of peers and seniors at the workplace. Furthermore, adequate family support, self-enthusiasm, and strong passion help them to maintain their focus on career advancement. 
The limitation of this study was a very small number of interviews, thus a large scale studies on the subject are required to gain in-depth insight about the contributing factors responsible for this imbalance between graduating and practicing lady surgeons.

\section{CONFLICT OF INTEREST:}

The authors declared no conflict of interest.

\section{AUTHORS' CONTRIBUTION:}

AAN: Conceived, designed and did data collection and interpretation of data.

WS: Writing of manuscript.

SW: Review, editing, final approval and drafting of manuscript.

\section{REFERENCES}

1. World population 2021 [updated 02-03-2021; cited 2021 02-03-2021]. Available from: http://countrymeters. info/en/World.
2. Lawal T, Afolabi A. Factors influencing the choice of surgery as a career by preregistration interns. Afr Health Sci 2013; 13(3):814-9. doi: 10.4314/ahs.v13i3.42.

3. Riska E. Gender and medical careers. Maturitas 2011; 68(3):264-7. doi: 10.1016/j.maturitas.2010.09.010

4. Fatima N, Haider AA, Latif F, Raheed S, Ali AS. Problems of female medical graduates during their career in a developing country: Pakistan. Pak Postgraduate Med J 2014; 25(3):91-4.

5. Marti KC, Lanzon J, Edwards SP, Inglehart MR. Career and professional satisfaction of oral and maxillofacial surgery residents, academic surgeons, and private practitioners: Does gender matter? J Dental Education 2017; 81(1):75-86.

6. Morris JB, Leibrandt TJ, Rhodes RS. Voluntary changes in surgery career paths: A survey of the program directors in surgery. J Am Coll Surg 2003; 196(4):611-6. doi: 10.1016/ S1072-7515(02)01832-X. 